\title{
The Analysis of Tax Planning Implementation on Added Tax (Case Study at PT Toyotomo Indonesia and PT RKN Forge Indonesia)
}

\author{
Dian Hakip Nurdiansyah, Eva Theresna Ruchjana, Moriska Alfarisi \\ Faculty Of Economic And Bussines Singaperbangsa Karawang University \\ dianhakip.nurdiansyah@staff.unsika.ac.id
}

\begin{tabular}{|l|}
\hline \multicolumn{1}{|l}{} \\
\hline How to cite (in APA style): \\
$\begin{array}{l}\text { Nurdiansyah, D, H., Ruchjana, E, T., Alfasari, M.(2020). The Analysis of Tax Planning Implementation on Added Tax } \\
\text { (Case Study at PT Toyotomo Indonesia and PT RKN Forge Indonesia). Jurnal Ekonomi dan Bisnis Jagaditha, 7(1), 18-23. } \\
\text { doi: https://doi.org/10.22225/jj.7.1.1365.18-23 }\end{array}$ \\
\hline
\end{tabular}

\begin{abstract}
Tax is one of the main sources of state revenue. The bigger the tax, the better the state finances. However, for the taxpayers, tax payments are a burden. On the other hand, the company is subject to state tax because its' activities are the tax object, which is a value-added tax. The aim of this study were to find out the policy of the implementation of Tax Planning of Value Added Tax implemented by PT Toyotomo Indonesia and PT RKN Forge Indonesia, to analyze the proper implementation of Tax Planning in the efficiency of the amount of Value Added Tax Payable, and to analyze the impact of the Tax Planning Implementation on Value Added Tax at PT Toyotomo Indonesia and PT RKN Forge Indonesia. The method used was descriptive quantitative. The data used in this research were primary and secondary data. The data collecting techniques used were interviews, observation, and documentation. The data analysis used was descriptive quantitative analysis with study case approach. The results of the research of Taxation Implementation at PT Toyotomo Indonesia and PT RKN Forge Indonesia related to Value Added Tax to efficient the VAT payable is good and in accordance with the applicable tax regulation. The impact of the tax planning implementation on VAT is minimizing the taxes by conducting activities that are likely to minimize the tax costs such as tax saving, avoiding violations of tax regulations, optimizing the creditable input tax, utilizing the $0 \%$ tax facilities.
\end{abstract}

Keywords: Input Tax, Output Tax., Tax Planning

\section{INTRODUCTION}

The company is one form of legal entity that becomes a business partner of the government, in which the business is more profit-oriented for the sake of the company's survival. Additionally, a company often suppresses the production costs and suppresses other costs so as to reduce or minimize the company's expenses. One of the problems that companies often encounter today is taxes.

PT Toyotomo Indonesia is a manufacturing company engaged in the field of heavy duty automotive, which is excavator spare parts and PT RKN Forge Indonesia is a manufacturing company engaged in the field of heavy duty automotive which is Hino vehicle spare parts. At the time of purchasing the merchandise or not merchandise, the company will also be subjected to Value Added Tax which is called the input tax.

PT RKN Forge Indonesia has VAT overpayment in 2016 as much as IDR $37,501,379,754.00$ with the VAT Output as much as IDR 8,273,026,268.00 and Input VAT as much as IDR $8,341,638,277.00$ and VAT overpayment in 2015 that is compensated to 2016 as much as IDR 37,433,127,745.00.

Indonesia is not the only country with Tax Planning to minimize the taxes payment to the government; other large countries also have tax law on Tax Planning. There are many perspectives on why the tax planning is implemented. One of which is a determinant factor of the company's financial policy, to lower tax payment so as to stabilize the company's profit. 
Tax Planning on Value Added Tax can be done by maximizing creditable Input VAT, obtaining Taxable Goods or Taxable Services from Taxable Entrepreneurs, postponing making tax invoices on the sale of Taxable Goods or Taxable Services for which the payment has not been received, no later than the end of the month after the Tax Period ends and postponing the deposit of Value Added Tax until the end of the following month after the Tax Period ends.

The aim of this study were to find out the policy of the implementation of Tax Planning of Value Added Tax implemented by PT Toyotomo Indonesia and PT RKN Forge Indonesia, to analyze the proper implementation of Tax Planning in the efficiency of the amount of Value Added Tax Payable, and to analyze the impact of the Tax Planning Implementation on Value Added Tax at PT Toyotomo Indonesia and PT RKN Forge Indonesia.

\section{CONCEPTUAL FRAMEWORK}

\section{Accounting}

(Riahi \& Belkoui, 2011) states that accounting is a process of identifying, measuring, and communicating economic information to allow for consideration and decision making based on the information by users of such information. According to (Surya, 2013) that accounting is a process of identifying, recording and communicating the economic information of an entity (e.g. a company, an organization) to a concerned user.

\section{Tax Accounting}

(Supriyanto, 2011) states that tax accounting is a process of recording, classifying, and summarizing a financial transaction in relation to tax obligations and ended with the preparation of fiscal financial statements in accordance with the relevant taxation provisions and regulation as the basis for the preparation of annual notification letters. (Widyaningsih, 2011) states that tax is a contribution to the state treasury based on the law so that it can be imposed with no direct repayment.

\section{Function of Tax}

(Resmi, 2011) argues that tax has several functions, namely:

\section{Receiver function(budgetair)}

Tax is a source of government revenue to finance expenditures both routinely and developmentally.

\section{Regulating function (regulerend),}

Tax is a tool to regulate or implement government policies in the social and economic field as well as achieving certain objectives outside the financial field.

\section{Valued Added Tax (VAT)}

Value Added Tax (VAT) is the tax imposed on the Delivery of Taxable Goods and Taxable Services produced, delivered and consumed in the Customs Area either the consumption of goods or services performed by Taxable Entrepreneurs. (Supriyanto, 2011) states that value-added tax is a tax levied/ deducted by a taxable entrepreneur related to the transactions of taxable goods/services in the customs area performed by either corporate or personal taxpayer.

\section{Tax Invoice}

According to Article 1 paragraph 23 Law on VAT Number 42 of 2009: "Tax Invoice is proof of tax levy made by Taxable Entrepreneurs conducting the delivery of Taxable Goods or delivery of Taxable Services." According to (Mardiasmo, 2011) tax invoice is made in:

Upon delivery of Taxable Goods or Taxable Services.

Upon receiving payment in the event of payment receipt occurred before the delivery of Taxable Goods or Taxable Services.

Upon the receipt of term payment in the case of partial delivery of the work phase.

Upon other times regulated by or based on the Regulation of Minister of Finance.

\section{Tax Planning}

Meanwhile, according to Hoffman in (Ompusunggu \& Arles, 2011) that Tax planning is a capacity owned by the taxpayer to arrange financial activities in order to obtain minimum tax expense.

\section{General Strategy of Tax Planning \\ Tax Saving}

is an effort of tax expense efficiency through the selection of taxation alternatives as a lower rate. For example, a company with taxable income of more than IDR 100 million may make a change in awarding fringe benefit to employees into allowances in the form of money.

\section{Tax avoidance}

is an effort of tax expense efficiency by avoiding taxation through transactions of nontaxable objects. For example, companies that 
still suffer loss, need to change employee benefits from money into fringe benefits because fringe benefit is not an object of income tax in Article 21. Thus, a tax savings occur.

Avoid violations of tax regulation

Mastering the applicable tax regulation, the company can avoid the incidence of tax sanctions, among others:

Administrative sanctions in the form of fine, interest, or increase

Penal or criminal sanctions.

\section{Delay the payment of tax liability}

Delay the payment of tax liability without violating the applicable regulations can be done through VAT payment delay. This delay is made by delaying the issuance of the output tax invoice until the permitted time limit, especially for credit sales. In this case, the seller may issue the tax invoice at the end of the following month after the delivery of the goods.

\section{Optimize the allowable taxcredit}

Taxpayers often lack information about payment of taxes that can be credited which is prepaid taxes. For example, Income Tax Article 22 on the purchase of diesel and import and foreign fiscal over the official travel of employees.

\section{METHODS}

Data or information collected should be relevant to the problem under study, meaning that data should be related, appropriate and proper. The data sources of this study consist of primary data and secondary data. Primary data is data obtained directly from the original source or the object under study. In this research, the primary data was obtained by direct interviews with the parties of the company, such as the head of the company and the head of finance and accounting department. While secondary data is a source of research data obtained by the researcher indirectly through intermediary media. In this study, secondary data was obtained through the company documents in the form of fiscal financial statements of the company, such as other documents. In this research, the data analysis used was descriptive quantitative analysis with study case, which is by describing or explaining the research results and comparing it with the generally accepted theory, so that the events occurred during research will be analyzed and then will continuously analyzed as long as the research is conducted.

\section{RESULT AND DISCUSSION}

The comparison of Tax Planning Implementation in PT Toyotomo Indonesia and PT RKN Forge Indonesia

\author{
Value Added Tax of PT Toyotomo \\ Indonesia
}

From the comparison had been conducted, the VAT payable by crediting the Input VAT can be seen clearly. By crediting the Input VAT, then PT Toyotomo Indonesia has saved VAT payable of IDR 109,337,232. Therefore, it is best for the entrepreneurs to maximize the Input VAT that can be credited for VAT payable can be more cost-effective.

\section{Value Added Tax of PT RKN Forge Indonesia}

Below is the data of Value Added Tax of PT RKN Forge Indonesia in April 2016 March 2017. From the comparison, the VAT payable by crediting the Input VAT can be seen clearly. Maximizing Input VAT that can be credited makes PT RKN Forge Indonesia has VAT overpayment that has been compensated to the next Tax Period, so that at the beginning of the 2016 Tax Period, the VAT Payable is still overpaid.

\section{Analysis of VAT Planning Implementation based on VAT Law No. 42 of 2009}

The following is the comparison of the Analysis of VAT Planning Implementation based on VAT Law No. 42 of 2009 at PT Toyotomo Indonesia and PT RKN Forge Indonesia:

\section{Analysis of 5 Value Added Tax Planning Strategies}

Below is the comparison of the Analysis of 5 Value Added Tax Planning Strategies at PT Toyotomo Indonesia and PT RKN Forge Indonesia in table 2:

By performing a comparison of the Value Added Tax between PT Toyotomo Indonesia and PT RKN Forge Indonesia, comparison of Analysis of VAT Planning Implementation based on VAT Law No.42 of 2009 at PT Toyotomo Indonesia and PT RKN Forge Indonesia, comparison of Analysis of 5 Value Added Tax Planning Strategies at PT Toyotomo Indonesia and PT RKN Forge Indonesia, it can be seen that the Value Added Tax at PT Toyotomo Indonesia still has underpaid VAT while PT RKN Forge Indonesia has overpaid VAT, PT Toyotomo Indonesia and PT RKN Forge Indonesia have 
different fiscal year, PT Toyotomo Indonesia has the same fiscal year as the calendar year that is Januari - Desember, while PT RKN Forge Indonesia has different fiscal year as the calendar year, that is April - March. The comparison of Value Added Tax at PT Toyotomo Indonesia which has underpaid VAT and PT RKN Forge Indonesia which has Overpaid VAT is very clear because PT Toyotomo Indonesia use Local Raw Materials or conduct Taxable Goods transaction from inside the country so that it has smaller Input Tax compared to Input Tax from Import. PT RKN Forge Indonesia conduct Taxable Goods purchase of almost $50 \%$ from import or abroad so that it has more creditable Input Tax and utilize the $0 \%$ tax rate for export, therefore, PT RKN Forge Indonesia since the first year has Overpaid VAT because it continues to have foreign transaction. PT RKN Forge Indonesia has never conducted the Overpaid VAT return but conducted Overpaid VAT by compensated it to the following year. From the Analysis of Value Added Tax Planning Implementation based on VAT Law No. 42 of 2009 at PT Toyotomo Indonesia and PT RKN Forge Indonesia has been in accordance to the applicable tax regulation. From the Analysis of 5 Value Added Tax Planning Strategies at PT Toyotomo Indonesia and PT RKN Forge Indonesia, it is in accordance to the existing theory.

Table 1

The comparison of VAT Planning Implementation based on VAT Law No. 42 of 2009 at PT Toyotomo Indonesia and PT RKN Forge Indonesia

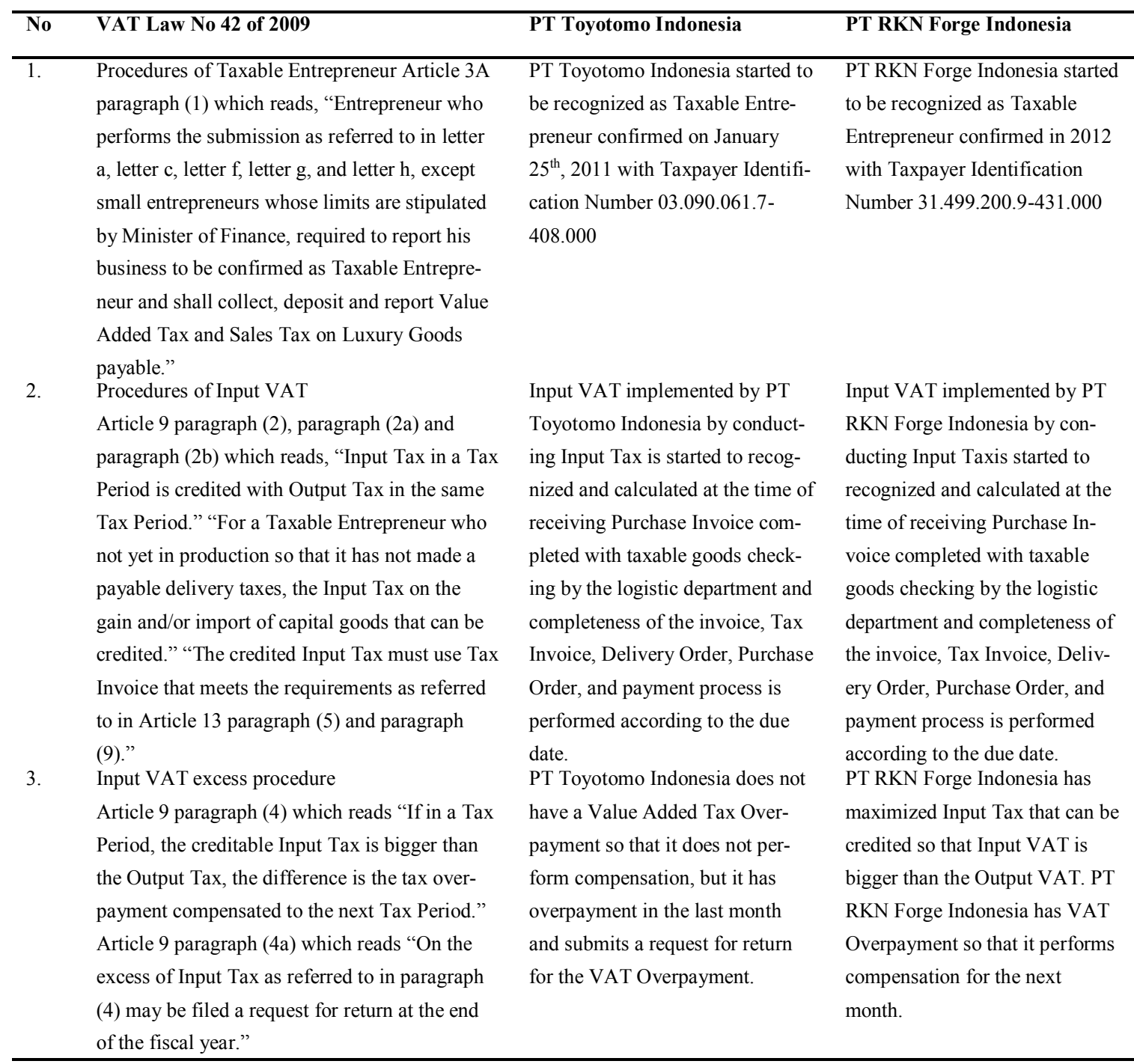




\begin{tabular}{|c|c|c|c|}
\hline 4. & $\begin{array}{l}\text { Output VAT procedure } \\
\text { Article } 7 \text { paragraph (1) which reads "Value } \\
\text { Added Tax Rate is } 10 \% \text { (ten percent)." } \\
\text { Article } 8 \text { A paragraph (1) which reads } \\
\text { "Value Added Tax payable is calculated by } \\
\text { multiplying the rate as referred to in article } \\
7 \text { with the Tax Imposition Basis which } \\
\text { includes Selling Price, Reimbursement, } \\
\text { Import Value, Export Value or other val- } \\
\text { ue." }\end{array}$ & $\begin{array}{l}\text { Collecting the Output VAT on PT } \\
\text { Toyotomo Indonesia is conducted } \\
\text { every transaction of Taxable Goods } \\
\text { delivery to the customer at the rate of } \\
10 \% \text { of the Tax Imposition Basis on } \\
\text { Taxable Goods on the Tax Invoice }\end{array}$ & $\begin{array}{l}\text { Collecting the Output VAT on PT } \\
\text { RKN Forge Indonesia is conducted } \\
\text { every transaction of Taxable } \\
\text { Goods delivery to the customer at } \\
\text { the rate of } 10 \% \text { of the Tax Imposi- } \\
\text { tion Basis on Taxable Goods on } \\
\text { the Tax Invoice }\end{array}$ \\
\hline 5. & $\begin{array}{l}\text { VAT Deposit Procedure } \\
\text { Article 15A paragraph (1) which reads } \\
\text { "The deposit of Value Added Tax by the } \\
\text { Taxable Company as referred to in Article } \\
9 \text { paragraph (3) shall be made no later than } \\
\text { the end of the following month after the } \\
\text { end of Tax Period and before the Notifica- } \\
\text { tion of Value Added Tax Period is submit- } \\
\text { ted." }\end{array}$ & $\begin{array}{l}\text { Deposit of Value Added Tax (VAT) } \\
\text { of PT Toyotomo Indonesia is con- } \\
\text { ducted at the latest of the end of the } \\
\text { following month after the end of Tax } \\
\text { Period and before the Notification of } \\
\text { Value Added Tax Period is reported } \\
\text { to the Tax Office. }\end{array}$ & $\begin{array}{l}\text { Deposit of Value Added Tax } \\
\text { (VAT) ofPT RKN Forge Indonesia } \\
\text { is conducted at the latest of the end } \\
\text { of the following month after the } \\
\text { end of Tax Period and before the } \\
\text { Notification of Value Added Tax } \\
\text { Period is reported to the Tax Of- } \\
\text { fice. }\end{array}$ \\
\hline 6. & $\begin{array}{l}\text { VAT Reporting } \\
\text { Article 15A Paragraph (2) "Notification of } \\
\text { Value Added Tax Period shall be submitted } \\
\text { no later than the end of the following } \\
\text { month after the end of the Tax Period." }\end{array}$ & $\begin{array}{l}\text { PT Toyotomo Indonesia reports any } \\
\text { activities of the Delivery and Acqui- } \\
\text { sition of Taxable Goods by e-SPT } \\
\text { Tax on Tax Planning in accordance } \\
\text { to the Law before the following } \\
\text { month after the Tax Period and make } \\
\text { the Electronic Deposit Letter(SSE). }\end{array}$ & $\begin{array}{l}\text { PT RKN Forge Indonesia reports } \\
\text { any activities of the Delivery and } \\
\text { Acquisition of Taxable Goods by e } \\
\text {-SPT Tax on Tax Planning in ac- } \\
\text { cordance to the Law before the } \\
\text { following month after the Tax } \\
\text { Period and make the Electronic } \\
\text { Deposit Letter (SSE). }\end{array}$ \\
\hline
\end{tabular}

Table 2

The comparison of 5 Value Added Tax Planning Strategies at PT Toyotomo Indonesia and PT RKN Forge Indonesia

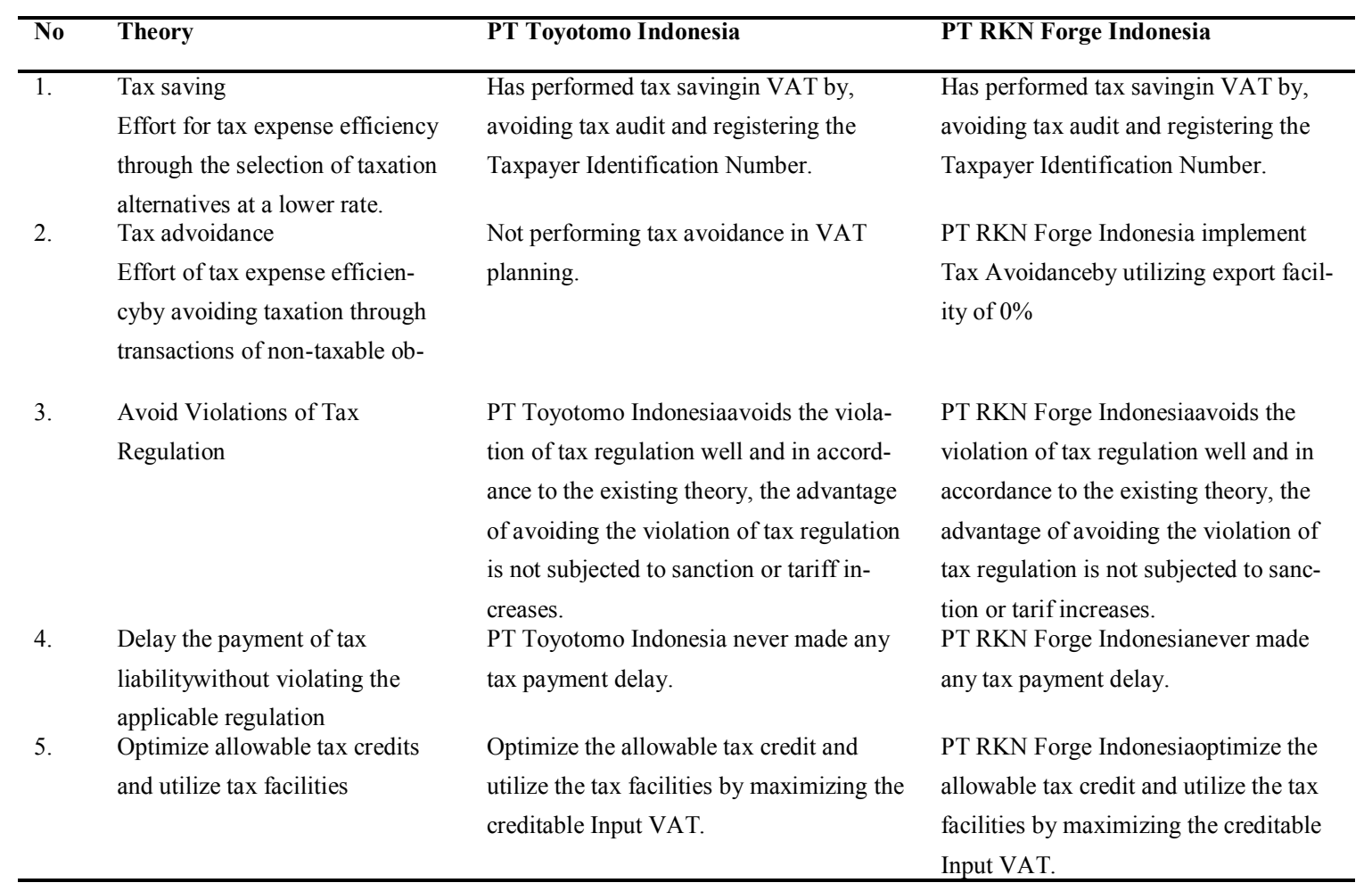




\section{CONCLUSION}

Based on the result and discussion of tax planning on Value Added Tax which has been described above, therefore it can be concluded that tax planning of PT Toyotomo Indonesia and PT RKN Forge Indonesia related to value added tax are in accordance with the applicable tax regulations, the Value Added Tax (VAT) treatment which has been done by PT Toyotomo Indonesia and PT RKN Forge Indonesia has been conducted in accordance with the applicable tax regulation which is proven by not receiving warning from the Tax Office, and the impact of implementing VAT tax planning at PT Toyotomo Indonesia and PT RKN Forge Indonesia is well, by using Value Added Tax Planning Strategy which is in accordance with the taxation regulation in Law Number 42 of 2009 on Value Added and Sales Tax on LuxuryGoods, PT Toyotomo Indonesia can save the Value Added Tax Payable, while PT RKN Forge Indoesia performs taxation facility, that is by using $0 \%$ tariff on export and maximize creditable Input Tax to save Value Added Tax.Doing Tax Planning is profitable for the companies without harming the state. PT Toyotomo Indonesia and PT RKN Forge Indonesia have also tried their best to avoid violation of tax laws in order not to be imposed by sanctions that could harm the company by making and reporting Value Added Tax (VAT) properly and on time.

\section{REFERENCES}

Mardiasmo. (2011). Perpajakan: Edisi Revisi. Yogyakarta: And Pustaka Publisher.

Ompusunggu, \& Arles, P. (2011). Cara Legal Siasati Pajak. Jakarta: Puspa Swara.

Resmi. (2011). Perpajakan: Teori dan Kasus. Jakarta: Salemba Empat.

Riahi, A., \& Belkoui. (2011). Teori Akuntansi (5th ed.). Jakarta: Salemba Empat.

Supriyanto. (2011). Akuntansi Perpajakan. Yogyakarta: Graha Ilmu.

Surya. (2013). Pengantar A kuntansi Berbasis IFRS Yogyakarta: Graha Ilmu Publisher.

Widyaningsih, A. (2011). Hukum Pajak dan Perpajakan. Bandung: Alfabeta Publisher. 